\title{
MERCOSUL E UNIÃO EUROPEIA: O ESTADO DA ARTE DOS PROCESSOS DE INTEGRAÇÃO REGIONAL, SEGUNDO KARINE DE SOUZA SILVA ${ }^{1}$
}

\author{
Guilherme Nazareno Flores ${ }^{2}$
}

1 SILVA, Karine de Souza. Mercosul e União Europeia: o estado da arte dos processos de integração regional. Florianópolis: Modelo, 2010. Karine de Souza Silva é professora dos Programas de Pós-graduação stricto sensu em Relações Internacionais e em Direito da Universidade Federal de Santa Catarina. É titular da Cátedra Jean Monnet - outorgada oficialmente pela União Europeia. Vice-coordenadora do curso de Graduação em Relações Internacionais/ UFSC. Estágio pós-doutoral em Relações Internacionais no \&quot; Institute for International and European Policy\&quot; da Katholieke Universiteit Leuven/Bélgica. Doutora e Mestre em Direito (com concentração em Relações Internacionais) pela Universidade Federal de Santa Catarina; Estágio Doutoral na Universidad de Sevilla /Espanha. Pós-graduação lato sensu em Integração Regional na Universidad Internacional de Andalucía, Espanha. Realizou visitaestágio no Tribunal de Justiça da União Europeia, em Luxemburgo e no Parlamento Europeu, em Bruxelas. Professora convidada da Universidade do Minho, em Portugal e da Universidad de Valladolid, Espanha. Consultora ad hoc do CNPq, da CAPES, da FAPESC e do MEC. Participou como observadora da Missão das Nações Unidas para estabilização do Haiti (MINUSTAH). É coordenadora do EIRENĖ: Núcleo de Pesquisas sobre Integração Regional, Paz e Segurança Internacional. Tem experiência na área de Organizações Internacionais, com ênfase em: 1) União Europeia; 2) O papel das Organizações Internacionais na promoção/manutenção da paz e da efetivação dos Direitos Humanos. Os principais temas de interesse acadêmico são: Direito da União Europeia, as relações entre a União Europeia e a América Latina/Mercosul/ Brasil; A OEA e o Conselho da Europa e a efetivação do Direito Internacional dos Direitos Humanos (a jurisprudência das Cortes Interamericana e Europeia de Direitos Humanos); a participação da União Europeia e do Brasil nas missões da paz da ONU; a Missão das Nações Unidas para estabilização do Haiti (MINUSTAH).

2 Doutorando e Mestre em Direito pela Universidade do Vale do Itajaí (UNIVALI), em, Itajaí, Santa Catarina, Brasil com linha de pesquisa em Direito Ambiental, Sustentabilidade e Transnacionalidade. Policial Militar e Professor Universitário. E-mail: guilhermeflores.adv@gmail.com. 
resenha da obra em questão em que é autora a Dra. Karine de Souza
Silva originou-se nas pesquisas para tese doutoral deste autor,
bem como em estudos realizados durante a disciplina "Estructura Institucional de la Unión Europea", cursada na Universidade de Alicante, Espanha, ainda durante o curso de doutoramento.

O objetivo central da obra é o de estabelecer uma análise sobre os processos de integração regional existentes no Mercosul e na União Europeia. Neste contexto, apesar de os objetivos e de as finalidades aparentemente serem os mesmos, parece óbvio que os dois continentes sofrem processos distintos de integração. Isto porque cada qual possui sua cultura, sua política econômica e outras especificidades.

Mesmo assim, o contexto abordado pelo livro em comento denota uma vontade de estabelecer vínculos entre um e outro continente; estabelecer paralelos entre uma e outra realidade, estabelecendo comparações no sentido de se trocar experiências úteis ao desenvolvimento conjunto das duas entidades.

A obra, que se divide em oito capítulos, inicia-se no trato de aspectos históricos, políticos e jurídicos do processo de integração europeia e as fases desse desenvolvimento iniciado na década de 1950 com a união de apenas seis estados.

Para se tornar como se conhece e se vive atualmente, a União Europeia, com tal caráter de supranacionalidade, sofreu muitos avanços e retrocessos no seu processo de integração. Este amadurecimento presenciado atualmente ocorreu principalmente pela intervenção e pela articulação pacífica e habilidosa de Jean Monnet como mentor deste processo, sendo este, junto de Robert Schuman, os principais protagonistas desta realidade.

A paz era tarefa hercúlea no contexto pós-guerra. Notava-se ressentimento dos vencidos, devastação social, cultural e econômica, temor do renascimento da Alemanha e da dependência econômica aos Estados Unidos, principalmente no que se refere à transferência de parcelas de soberania num modelo jamais visto no mundo.

O segundo capítulo trata dos motivos carecedores de "acertos" e que desgastam o processo de integração atualmente. Um destes embates é a adesão da Turquia 
à União Europeia, por sua vez fomentado principalmente pela diferença cultural e religiosa, já que a Turquia, passando a fazer parte da UE, será o único país de origem islâmica, enquanto que os demais 27 estados possuem origem judaico-cristã.

Se por um lado a posição geográfica turca pareça ser um ponto de interesse econômico do bloco, num prisma diametralmente oposto, a fobia ao Islã decorrente especialmente do "pós-11 de setembro", sua proximidade ao Iraque, Síria e Irã, a existência de conflitos armados com alguns deles e a possibilidade de movimentos terroristas no continente devido à ligação entre terrorismo e islamismo foram decisivos contra a adesão turca.

Na análise do terceiro capítulo, a obra trata das alterações introduzidas à UE pelo Tratado de Lisboa em uma conjuntura política na qual predominava a falta de consenso para a criação de uma Constituição Europeia. O instrumento altera os Tratados de Roma e de Maastricht, conferindo à UE um enquadramento jurídico e ferramentas que lhe permitem fazer face aos desafios do mundo globalizado e que não conhece fronteiras. Por meio deste instrumento, a União Europeia passa a ser uma entidade única, dotada de personalidade jurídica própria, e mais forte para enfrentar as questões globais, políticas, econômicas e sociais do bloco e do mundo.

A obra aborda os paradoxos havidos na polêmica "Diretiva do Retorno", eis que trata da deportação de forma sumária dos imigrantes em situação irregular, criminalizando-os. Por isto a diretiva ficou também conhecida por "Diretiva da Vergonha", o que representa um retrocesso aos Direitos Humanos e Fundamentais, ao Direito Internacional e aos avanços já obtidos pela União Europeia nestes quesitos.

Os êxitos, os dilemas e as perspectivas da integração do Mercosul, bem como do aspecto histórico e especificidades do processo de integração na América Latina, são abordados no sexto capítulo. Seguindo a tendência de globalização, os processos de integração regional e formação de blocos econômicos vêm ocorrendo no mundo todo com objetivo de fortalecimento econômico, e todos tomam por base a Europa.

É certo que América Latina e Europa possuem diferenças culturais, econômicas, históricas, que não permite esperar que a integração 
regional latino ocorra com facilidade. Um grande e recorrente desafio está na natureza das instituições do Mercosul e na necessidade de defini-las por intergovernamentais ou supranacionais.

O Mercosul adotou o sistema de intergovernamentabilidade, no qual as decisões do bloco estão atreladas à vontade política dos Estadosmembros e as normas produzidas no âmbito integracionista devem ser internalizadas para produzirem efeitos jurídicos. Isto visa ao controle político do bloco, possibilitando o veto de decisões que poriam em risco a soberania dos países membros e obstaculizam a quista integração. Para tanto, os Estados-membros ainda precisam definir em conjunto questões voltadas à Soberania, à organização política, ao desenvolvimento econômico, à integração cultural, etc., para que possam chegar ao objetivo comum.

O sexto capítulo trata dos fundamentos e do desenvolvimento do Mercosul no contexto do processo evolutivo de seus estados que vêm procurando se desvincular de políticas protecionistas para se adaptarem a uma difícil e competitiva convivência internacional. Para Silva, foi por meio da liberdade de concorrência estabelecida no rol de liberdades fundamentais que a União Europeia, quando estava na fase hoje vivenciada pelo Mercosul, conseguiu chegar à fase de "mercado comum". O desenvolvimento de um direito forte também é primordial para trazer avanços ao bloco.

Quanto à criação de um Parlamento do Mercosul, abordada no sétimo capítulo, a autora destaca que tal órgão deve ser suficiente para que seu produto, a lei, possa ser corroborada por todos os países que compõem o bloco para que neles tenha validade. Busca-se um controle não apenas legal, mas também político, no desejo de uma cultura de democracia participativa e de representatividade civil, de pluralidade ideológica e política que deve permear todos os sulamericanos, indistintamente. 
Finalmente, a coesão social havida no âmbito do Mercosul por meio do desenvolvimento econômico e da integração regional é tratada no oitavo ponto da obra. A autora busca destacar que o Mercosul não deve pautar-se pela simples coesão econômica ou livre comércio. Há uma vontade de situar a integração regional como pré-requisito para se alcançar a coesão social no âmbito do Mercosul, garantindo, desta forma, uma inserção adequada dos Estados-membros no sistema internacional.

Os países sul-americanos, contudo, sempre demonstraram sua condição de desigualdade social, desarticulação política, econômica e sociais. Por conta disto, necessitam uma mudança urgente neste sentido para garantir a ruptura da subordinação do poder hegemônico.

Esta necessidade de coesão social, por fim, ocorrerá com esforços e acordos entre os governos e o Mercosul, num clima de colaboração mútua, buscando maturidade para a integração total do bloco. 